\title{
Implementation of Voluntary Instruments by Czech Enterprises to Meet Sustainability and Competitive Growth
}

\section{- Pavla Vrabcova, Hana Urbancova}

\begin{abstract}
A responsible business reflects the fundamental values of a society and is important for all enterprises. It can improve their economic, environmental, and social characteristics from a short- and long-term perspective through innovative products and services, new capabilities, and stakeholder involvement. This study aims to identify the common convergent factors of voluntary instruments in management systems to achieve sustainable business and competitive growth. There are several tools aimed at achieving sustainability and competitiveness, an important component of which is the subject of this study: the voluntary approach. To determine the key factors of this approach, we used the online questionnaire technique of data collection ( $\mathrm{n}=$ 183). We also conducted exploratory analysis with factors estimated by the principal components and orthogonal rotation using the varimax method. Relevant driving forces are identified in the development of the business models of sustainability and competitiveness, including the integration of quality, environment and occupational safety and health management systems, the environmental profile of the organisation for economic and social affairs, voluntary reporting of environmental activities, and evaluation of environmental impacts. These factors make a significant contribution towards improving environmental sustainability while ensuring competitive business. The ability to move quickly and successfully to these business models is an important source of sustainable competitive advantage.
\end{abstract}

Keywords: environmental responsibility, economic sustainability, integrated management systems, social responsibility, sustainable development JEL Classification: M12, M14, M19

Received: February, 2021

1st Revision: July, 2021

Accepted: August, 2021

\section{INTRODUCTION}

Previous studies have shown that humanity is facing decreasing ecosystem quality (Broman \& Robèrt, 2017; Kajikawa et al., 2014; Orecchini et al., 2012; Steffen et al., 2015), population growth (Kopnina, 2017), poverty (Cuaresma et al., 2018), global inequality (Diffenbaugh \& Burke, 2019; 
Orecchini et al., 2012), climate change (Ahmed, 2020), decreasing biological diversity (Kopnina, 2017), breach of trust (Broman \& Robèrt, 2017), and globally inadequate economic growth (Orecchini et al., 2012). With respect to urgent social and environmental needs, sustainability science is expected to play an important role in gaining expertise and contribute to the realisation of a sustainable society (Kajikawa et al., 2014; Spangenberg, 2011). Global networks are created for research in the area of sustainability and cooperation between industry and academic spheres (Orecchini et al., 2012). In the academic sphere, a broadly conceived implementation of education promoting sustainable development can be mentioned (O'Flaherty \& Liddy, 2018), which is absolutely necessary (Wiek et al., 2012). Over decades, several researchers such as Fischer et al. (2017), Hummels \& Argyrou (2021), Missimer (2017), and Rauter et al. (2017) have agreed that the term 'sustainable development' is unclear and ambiguous. According to Hummels \& Argyrou (2021), sustainable development can be seen, at best, as development meeting contemporary needs, corresponding planetary boundaries, and not jeopardising the capability of future generations to meet their needs without crossing the planetary boundaries. Hák et al. (2016) warn that given the high number of goals that come under sustainable development, numerous indicators can be expected, and they suggest a solution consisting of a larger set of indicators and a small set of key indicators that meet certain criteria, such as intelligibility, timeliness, and scope.

As documented by Hummels \& Argyrou (2021), one way to overcome the dichotomy between the contemporary needs of today and the needs of the future generations and tension between discourses is sustainable business. Some authors (Kolk \& Van Tulder, 2010) consider corporate social responsibility (CSR) as a key contribution of society to sustainable development. Interest in creating a sustainable society has been developing among politicians, corporations (see, for example, the World Business Council for Sustainable Development and its Czech branch), and the general public, and it has become a mission of educational and research programs worldwide. Entrepreneurship that is not only focused on short-term profits but also considers the principles of long-term sustainability can be referred to as sustainable entrepreneurship. Moreover, CSR initiatives are often closely related to sustainable business practices (Ahi \& Searcy, 2013). Van Marrewijk (2003) considers these terms to be synonymous. Several analyses of CSR definitions have been published, focussing on the needs of key stakeholders from a long-term perspective and the key characteristics of economic, environmental, and social pillars (Cancino et al., 2018; Ciccullo et al., 2018). However, organisations fear the financial impacts of CSR; regardless of its strategic advantages (Camacho \& Fernandez, 2018; Gallardo-Vázquez \& Sanchez-Hernandez, 2014; Hung et al., 2019; Petř́ček et al., 2021), and empirical findings concerning the impact of CSR on corporate finance are rather mixed (Bhardwaj et al., 2018). The most frequently mentioned benefit is maintaining competitiveness (Gallardo-Vázquez \& Sanchez-Hernandez, 2014; Hadj, 2020; Jorge et al., 2015; Nyuur et al., 2019; Yu et al., 2017). However, Marin et al. (2017) fail to demonstrate any direct influence of CSR on competitiveness, but show that innovation and investment have an indirect influence thereon.

Sustainable business engenders competitiveness (Drobyazko et al., 2019). Depending on the research perspective, competitiveness can have a range of different meanings and levels: global, national, regional, or industrial; however, ambiguities about the research perspective still exist. The scientific discipline of management provides diverse models and instruments 
for the evaluation and implementation of processes towards more sustainable and competitive production (Gonzalez et al., 2015). Sustainable development at the enterprise level in a highly competitive environment can emphasise the direction in which innovation activities develop, the active support of which is an integral part of business strategy and the overall approach of management (Rauter et al., 2017).

This study deals with voluntary instruments in the management systems of enterprises in the Czech Republic across sectors, with qualitative research focussed on agricultural enterprises and their attitudes to the voluntary instruments with regard to current challenges in agriculture. Agriculture is characterised by relatively intense competition, removal of barriers, rapid technological development and related globalisation to which companies must respond by constantly actively seeking their competitive advantages, which can be understood as the company's long-term ability to generate perceived utility and achieve above-average profits.

\section{THEORETICAL BACKGROUND}

Thanks to responsible business, organisations of all sizes, in collaboration with their stakeholders, can assist in achieving balance in the realisation of economic, social, and environmental goals (Evans et al., 2017; Young \& Tilley, 2006), and the pressure on them is intense in this context (Joyce \& Paquin, 2016). New modern theories of managerial thinking and acting prioritise the application of synergic effects (Akhmadovich, 2019; Ren et al., 2018). The responsible business has become an increasingly important topic in the discourse on globalisation (Mahdi et al., 2019; Zhai et al., 2018), competitiveness (Bernal-Conesa et al., 2017; Haseeb et al., 2019) and sustainable development (Lopez, 2020; Lüdeke-Freund \& Dembek, 2017). Nevertheless, there is no universal system of management (Nosratabadi et al., 2019), only systems that can efficiently assist management rationalisation depending on the conditions in which they are implemented. The research on sustainable development has been continually extended in the scientific discipline of management, which is documented in published studies, for example, Rauter et al. (2017) and Zemigala (2019). The integrated managerial system (Evans et al., 2017; Nosratabadi et al., 2019; Rauter et al., 2017) is an opportunity for organisations to demonstrate their commitment to sustainable development in the area of customer and stakeholder relations, as well as in relation to the environment and occupational safety and health (OSH), and managerial information safety. Each stakeholder (Geissdoerfer et al., 2018; Stubbs, 2017) affects the competitiveness of the organisation in a certain way. Lozano (2015) claims that sustainability comprises a holistic concept with five dimensions (Joyce \& Paquin, 2016). Owners and shareholders are interested in the growth and prosperity of the organisation, employees evaluate working conditions, customers are interested in the quality of products and services, governments are interested in reducing unemployment and creating suitable business conditions, and citizens are interested in the behaviour of organisations in their places of operation. The present study focuses on the application of the following voluntary instruments that are identified based on research (see Table 1). 
Tab. 1 - Voluntary activities, tools, and approaches in the context of the pillars of sustainable business for competitive growth in enterprises. Source: own research

\begin{tabular}{|c|c|c|c|c|}
\hline Pillar & $\begin{array}{l}\text { Voluntary } \\
\text { activity, tool, } \\
\text { approach }\end{array}$ & Principle & Reference & \multirow{6}{*}{$\begin{array}{l}\text { Non-financial } \\
\text { reporting and } \\
\text { sustainable } \\
\text { development } \\
\text { reporting, } \\
\text { for example, } \\
\text { Global Report- } \\
\text { ing Initiative } \\
\text { (Tarquinio et } \\
\text { al., 2018) } \\
\text { Integration } \\
\text { of quality } \\
\text { management } \\
\text { systems, health } \\
\text { and safety and } \\
\text { environment } \\
\text { (Mustapha et } \\
\text { al., 2017) }\end{array}$} \\
\hline Economic & $\begin{array}{l}\text { Quality } \\
\text { management } \\
\text { systems }\end{array}$ & $\begin{array}{l}\text { Customer focus, leadership, } \\
\text { people commitment, pro- } \\
\text { cess approach, continuous } \\
\text { improvement }\end{array}$ & $\begin{array}{l}\text { Nguyen et } \\
\text { al. (2018) }\end{array}$ & \\
\hline \multirow{3}{*}{ Social } & CSR Report & $\begin{array}{l}\text { Communication with the } \\
\text { internal and external envi- } \\
\text { ronment - company values, } \\
\text { market behaviour, relation- } \\
\text { ship with employees, local } \\
\text { community, environment, } \\
\text { stakeholder involvement }\end{array}$ & $\mathrm{Zu}(2019)$ & \\
\hline & $\begin{array}{l}\text { Health and } \\
\text { safety manage- } \\
\text { ment systems }\end{array}$ & $\begin{array}{l}\text { Search and assessment } \\
\text { of risks, categorisation, } \\
\text { technical and organisa- } \\
\text { tional requirements for the } \\
\text { work environment, work } \\
\text { organization and work pro- } \\
\text { cedures, employee training, } \\
\text { provision of personal pro- } \\
\text { tective equipment, safety } \\
\text { of technical equipment, } \\
\text { occupational hygiene, oc- } \\
\text { cupational health services, } \\
\text { safety signs and signals, } \\
\text { solutions accidents at work } \\
\text { and occupational diseases, } \\
\text { fire protection, crisis man- } \\
\text { agement. }\end{array}$ & $\begin{array}{l}\text { Jilcha \& } \\
\text { Kitaw } \\
(2017)\end{array}$ & \\
\hline & $\begin{array}{l}\text { Social innova- } \\
\text { tion }\end{array}$ & $\begin{array}{l}\text { A new solution to a persis- } \\
\text { tent social problem. }\end{array}$ & $\begin{array}{l}\text { Olsson et } \\
\text { al. }(2017)\end{array}$ & \\
\hline $\begin{array}{l}\text { Environ- } \\
\text { mental }\end{array}$ & $\begin{array}{l}\text { Environmental } \\
\text { management }\end{array}$ & $\begin{array}{l}\text { Waste prevention, more ef- } \\
\text { ficient use of raw materials } \\
\text { and fuels, water con- } \\
\text { sumption and wastewater } \\
\text { treatment, air emissions, } \\
\text { leakage of hazardous sub- } \\
\text { stances and contamination } \\
\text { of water and soil and more. }\end{array}$ & $\begin{array}{l}\text { Marchese } \\
\text { et al. (2018) }\end{array}$ & \\
\hline
\end{tabular}




\begin{tabular}{|c|c|c|c|}
\hline \multirow{6}{*}{$\begin{array}{l}\text { Environ- } \\
\text { mental }\end{array}$} & $\begin{array}{l}\text { Product life } \\
\text { cycle assess- } \\
\text { ment (LCA) }\end{array}$ & $\begin{array}{l}\text { Setting goals and scope, } \\
\text { life cycle analysis, environ- } \\
\text { mental impact assessment, } \\
\text { life cycle interpretation. }\end{array}$ & $\begin{array}{l}\text { Joyce \& } \\
\text { Paquin } \\
(2016)\end{array}$ \\
\hline & $\begin{array}{l}\text { Environmental } \\
\text { accounting }\end{array}$ & $\begin{array}{l}\text { Important data for the } \\
\text { success of environmental } \\
\text { management activities. } \\
\text { Collection, analysis and } \\
\text { communication. Conven- } \\
\text { tional accounting systems } \\
\text { do not accurately reflect } \\
\text { environmental costs and } \\
\text { benefits. }\end{array}$ & $\begin{array}{l}\text { Giang et al. } \\
(2020)\end{array}$ \\
\hline & $\begin{array}{l}\text { Environmental } \\
\text { audit }\end{array}$ & $\begin{array}{l}\text { Compliance audits, en- } \\
\text { vironmental risk audits, } \\
\text { management effectiveness } \\
\text { audits, environmental } \\
\text { management systems audits }\end{array}$ & $\begin{array}{l}\text { Balasub- } \\
\text { ramanian } \\
\text { \& Shukla } \\
(2020)\end{array}$ \\
\hline & $\begin{array}{l}\text { Environmental } \\
\text { labelling }\end{array}$ & $\begin{array}{l}\text { eco-labelling, Environmen- } \\
\text { tal Product Declaration, } \\
\text { individual environmental } \\
\text { claims }\end{array}$ & $\begin{array}{l}\text { Hayat et al. } \\
(2020)\end{array}$ \\
\hline & $\begin{array}{l}\text { Evaluation of } \\
\text { environmental } \\
\text { performance }\end{array}$ & $\begin{array}{l}\text { Define measurable indica- } \\
\text { tors for each goal and } \\
\text { determine in detail how en- } \\
\text { vironmental performance } \\
\text { is assessed. }\end{array}$ & $\begin{array}{l}\text { Mapar et } \\
\text { al. }(2020)\end{array}$ \\
\hline & $\begin{array}{l}\text { Environmental } \\
\text { communication }\end{array}$ & $\begin{array}{l}\text { One-way and two-way } \\
\text { communication: issuing } \\
\text { environmental messages to } \\
\text { stakeholders, formulation } \\
\text { of relevant ideas. }\end{array}$ & $\begin{array}{l}\text { McGreavy } \\
\text { et al. (2016) }\end{array}$ \\
\hline
\end{tabular}

According to the results of international studies (see Table 1), it can be summarised that CSR is currently an important strategic part of all the activities of every enterprise, regardless of its size. Its implementation, however, not only refers to social issues but also leads to a much more complex goal, which represents sustainable development throughout human society. The results confirm that social responsibility is currently at such an advanced level that it allows enterprises to gain a better position in the market, increase competitiveness, and create a unique competitive advantage over other businesses and competitors. However, this issue should not merely connote voluntary instruments of business entities but should be brought to the attention of all persons through their responsible behaviour; so that they can achieve the common goal of sustainable development. 


\section{RESEARCH OBJECTIVE, METHODOLOGY, AND DATA}

The instruments were identified through literary research in Czech and primarily foreign papers and monographs. Upon analysing professional resources (monographs, essays, papers) in professional databases, including Engineering Village, Elsevier, ISI Science Direct, Scopus, and Wiley, the following keywords and their variants were searched: sustainability of the environment, economic sustainability, social sustainability, performance measurement, sustainable development, and environmental management systems. Previous publications and other documents concerning sustainable development were reviewed within the research preparation, and the 25-year process of learning between scientists and practitioners was reflected. Literary research on voluntary instruments was conducted in a similar way as described above by searching the following keywords and their variants: CSR, pillars of CSR, triple bottom line, stakeholder, competitiveness, strategy, mission, vision, age-based management of human resources, age management, process management, environmental managerial accounting, ecosystem services, material flows, carbon footprint, sequestration, offset, environmental performance, life cycle assessment, reporting of sustainable development, and management systems. The questionnaire survey, which was designed to comply with ethical rules and the requirement for anonymity, was conducted from June to December 2020. The questionnaire contained 63 questions related to factors affecting competitive growth and ensuring a sustainable business model, and 5 identification questions were evaluated with multiple answer options. The questions were close-ended (allowing only provided response options) with adequate response options. The sample was based on the ALBERTINA database of organisations (more than 2,700,000 organisations registered in the Czech Republic). The questionnaire was distributed to companies through e-mail; 850 companies were contacted twice (with a reminder), and the rate of return of the questionnaire was $21 \%$. The structure of the organisations participating in the research $(\mathrm{n}=183)$ is as follows: the basic identifying features of the questionnaire survey included the sector of operation of the organisation (primary, secondary, and tertiary), size of the organisation, majority ownership, type of organisation (private, public, non-profit), and year turnover (see Table 2). The results can only be generalised to the study sample. The questionnaire was filled out in Google form by the middle or senior management of the organisation, while, in the case of smaller organisations, the form was filled by the owner.

Tab. 2 - Organisations participating in the research-basic data. Source: own research

\begin{tabular}{|c|c|c|c|}
\hline \multirow{2}{*}{ Characteristics } & \multicolumn{3}{|c|}{ Categories } \\
\hline \multirow{2}{*}{ Sector of operation of the organisation } & Primary & Secondary & Tertiary \\
\cline { 2 - 4 } & $4.4 \%$ & $41.5 \%$ & $54.1 \%$ \\
\hline \multirow{2}{*}{ Size of the organisation } & $<50$ & $51-249$ & $>250$ \\
\cline { 2 - 4 } & $26.2 \%$ & $28.4 \%$ & $45.4 \%$ \\
\hline \multirow{2}{*}{ Majority ownership } & Domestic & \multicolumn{2}{|c|}{ Foreign } \\
\cline { 2 - 4 } & $45.4 \%$ & \multicolumn{2}{|c|}{$54.6 \%$} \\
\hline \multirow{2}{*}{ Type of organisation } & Private & Public & Non-profit \\
\cline { 2 - 4 } & $85.8 \%$ & $11.5 \%$ & $2.7 \%$ \\
\hline
\end{tabular}




\begin{tabular}{|l|c|c|c|}
\hline \multirow{2}{*}{ Annual turnover } & $<10$ mil. EUR & $\begin{array}{c}11-50 \text { mil. } \\
\text { EUR }\end{array}$ & $>50$ mil. EUR \\
\cline { 2 - 4 } & $38.3 \%$ & $37.7 \%$ & $24.0 \%$ \\
\hline
\end{tabular}

A multidimensional statistical method of factor analysis is used to find hidden factors, the purpose of which is to reduce the number of variables (characterisation of $\mathrm{p}$ variables by a smaller number of common factors) and reveal the structure of relations among the variables. The relationship among the variables was established through factor analysis, where factors were estimated using principal component analysis and orthogonal rotation by the varimax method, which maximises the sum of variances of all factors. The varimax method of rotation is most frequently used in sociology and management (Anderson, 2013). The preconditions for the use of exploratory factor analysis are normally divided into continuous variables. The factor analysis model describes the observations using equation (1):

$X_{1}=a_{11} F_{1}+a_{12} F_{2}+a_{1 m} F_{m}+U_{1}+\mu_{1}$,

$X_{2}=a_{21} F_{1}+a_{22} F_{2}+a_{2 m} F_{m}+U_{2}+\mu_{2}$

$X_{p}=a_{p 1} F_{1}+a_{p 2} F_{2}+\ldots a_{p m} F_{m}+U_{p}+\mu_{p}$

where:

$\mathrm{X}_{1}, \ldots, \mathrm{X}_{\mathrm{p}}=$ observed variables,

$\mathrm{F}_{1}, \ldots, \mathrm{F}_{\mathrm{m}}=$ latent common factors,

$\mathrm{a}_{11}, \ldots, \mathrm{a}_{\mathrm{pm}}=$ factor loads,

$\mathrm{U}_{1}, \ldots, \mathrm{U}_{\mathrm{p}}=$ specific factors representing random deviations,

$\mu_{1}, \ldots, \mu_{\mathrm{p}}=$ constants.

For the orthogonal model of factor analysis, it applies that (2):

$\sum \mathrm{AA}^{\mathrm{T}}+\mathrm{D}$

where:

$A=$ matrix of factor loads, $a_{i j}$ is an element in the $i$ th row and $j$ th column of matrix $A$,

$\mathrm{D}=$ diagonal matrix with values $\mathrm{d}_{1}, \ldots, \mathrm{d}_{\mathrm{p}}$ on the diagonal.

To evaluate the appropriateness of factor analysis, the Kaiser-Meyer-Olkinova (KMO) degree of adequacy of selection is used, that is, an index comparing the magnitudes of the observed correlation coefficients and the magnitudes of the coefficients of partial correlation. The data in the questionnaire surveys meet the minimum KMO statistic value criterion (3):

$K M O=\frac{\sum_{i \neq j} r_{i j}^{2}}{\sum_{i \neq j} r_{i j}^{2}+\sum_{i \neq j} u}$,

where:

$\mathrm{r}_{\mathrm{ij}}=$ correlation matrix, 
$\mathrm{u}_{\mathrm{ij}}=$ partial covariance matrix.

The KMO value ranges between 0 and 1 (values closer to 1 are more appropriate). The minimum recommended value is 0.6. A suitable varimax extraction method is selected (Kaiser, 1958) as follows (4):

$V=\frac{1}{p} \sum_{j=1}^{m}\left\{\sum_{i=1}^{p}\left(\frac{\grave{l}_{i j}}{\grave{h}_{i}}\right)^{4}-\frac{1}{p}\left(\sum_{i=1}^{p}\left(\frac{\grave{l}_{i j}}{\grave{h}_{i}}\right)^{2}\right)^{2}\right\}$,

where:

$\mathrm{V}=$ varimax value,

$\mathrm{p}=$ specific variance,

$1_{\mathrm{ij}}=$ estimated factor loads,

$h_{i}=$ communality for the $i-$ th variable.

The qualitative survey, which focuses on sustainable development, is based on individual online interviews $(\mathrm{n}=8$ ) with owners and managers of agricultural organisations (they engage in business activities in the field of crop and animal production in agriculture across the sectors). Representatives of various agricultural enterprises were ensured as the respondents were selected with respect to the specific and basic areas of agriculture strongly colliding with sustainability, such as production, social and demographic roles, and ecological and landscaping roles of agriculture. Detailed interviews focussed on voluntary instruments aimed at ensuring sustainable business models and competitiveness. The interviews confirmed the data from the quantitative research, and further important research directions were found through the interviews. The KMO (4) value was calculated, and it met the minimum value of 0.76 recommended in the literature.

The IBM SPSS Statistics 24 software was used to evaluate the results.

The main goal of this study is to identify the common convergent factors of voluntary instruments in management systems to achieve sustainable business and competitive growth. This study attempts to answer the research question: What common factors are decisive in setting up the management system of selected enterprises with regard to ensuring sustainable business and competitive growth?

\section{RESULTS AND DISCUSSION}

The research results are presented in this section. Table 3 shows that in majority of the addressed enterprises (41\%), all processes and projects are evaluated with respect to their economic, environmental, and social aspects and impacts. In $22 \%$ of the enterprises, the main emphasis is on economic objectives (i.e. long-term profit). Regarding social affairs and attitudes towards the environment, compliance with applicable laws is ensured. The primary emphasis is on economic and social objectives for $27 \%$ of the enterprises, and the corporate approach to the environment is in line with environmental conservation laws. Economic and environmental objectives are emphasised in $9 \%$ of the enterprises; nevertheless, the measures applied in the social area comply with applicable laws (see Table 3). 
Tab. 3 - Organisations focussing on a system of three pillars according to their size. Source: own research

\begin{tabular}{|l|c|c|c|c|}
\hline \multirow{2}{*}{ Organisation focus } & \multicolumn{2}{|c|}{ Size of the organisation (number of } & \multirow{2}{*}{ Total } \\
\cline { 2 - 4 } & $>250$ & $51-249$ & $<50$ & \\
\hline $\begin{array}{l}\text { Organisation focus: economic and } \\
\text { environmental }\end{array}$ & $3.83 \%$ & $3.28 \%$ & $2.18 \%$ & \multirow{2}{*}{$9.29 \%$} \\
\hline $\begin{array}{l}\text { Organisation focus: economic and } \\
\text { social }\end{array}$ & $10.93 \%$ & $10.38 \%$ & $6.01 \%$ & $27.32 \%$ \\
\hline Organisation focus: economic & $9.29 \%$ & $3.83 \%$ & $9.29 \%$ & $22.41 \%$ \\
\hline $\begin{array}{l}\text { Organisation focus: economic, } \\
\text { environmental, and social }\end{array}$ & $21.31 \%$ & $10.93 \%$ & $8.74 \%$ & $40.98 \%$ \\
\hline Total & $45.36 \%$ & $28.42 \%$ & $26.22 \%$ & $100.00 \%$ \\
\hline
\end{tabular}

The system of the three pillars is emphasised in large organisations vis-à-vis the number of employees $(21 \%)$. Four factors are identified in the application of voluntary instruments, which explain $50 \%$ of the resulting behaviour of the sample. The strongest of them is Factor $1(24 \%)$ (see Table 4).

Tab. 4 - Primary component analysis: approaches to enforce sustainable business by means of voluntary instruments. Source: own research

\begin{tabular}{|l|l|l|l|}
\hline Factor & Total variance & Total \% of variance & Cumulative \% of variance \\
\hline 1 & 3.374 & 24.103 & 24.103 \\
\hline 2 & 1.465 & 10.463 & 34.566 \\
\hline 3 & 1.130 & 8.071 & 42.638 \\
\hline 4 & 1.037 & 7.404 & 50.042 \\
\hline
\end{tabular}

The first component (factor) is responsible for $24.1 \%$ of the variance in items, the second component is responsible for approximately $10.5 \%$ of the variance, and the third and fourth components are responsible for $8 \%$ and $7.4 \%$ of the variance, respectively. The cumulative percentage of variance $(50 \%)$ represents the current and all previous factors. Orthogonal rotation using the varimax method was performed with the aim of maximising the variance of each factor. Table 5 shows the results of the factor analysis in more detail (it applies that the higher the correlation, the more the factor saturated with the variable).

Tab. 5 - Factor loads in the four-factor solution after varimax rotation: approaches to enforce sustainable business by means of voluntary instruments. Source: own research

\begin{tabular}{|l|l|l|l|l|l|}
\hline Variable & NO/YES \% & Factor 1 & Factor 2 & Factor 3 & Factor 4 \\
\hline $\begin{array}{l}\text { Social innova- } \\
\text { tions }\end{array}$ & $53.0 / 47.0$ & 0.203 & $\mathbf{0 . 7 0 5}$ & -0.119 & 0.054 \\
\hline $\begin{array}{l}\text { Integrated man- } \\
\text { agement systems }\end{array}$ & $48.3 / 51.7$ & $\mathbf{0 . 6 4 3}$ & -0.106 & 0.358 & -0.034 \\
\hline
\end{tabular}




\begin{tabular}{|c|c|c|c|c|c|}
\hline $\begin{array}{l}\text { Quality manage- } \\
\text { ment systems }\end{array}$ & $53.0 / 47.0$ & 0.723 & 0.002 & 0.088 & 0.160 \\
\hline $\begin{array}{l}\text { Occupational } \\
\text { safety and health } \\
\text { (OSH) manage- } \\
\text { ment systems }\end{array}$ & $41.0 / 59.0$ & 0.563 & 0.287 & -0.088 & -0.039 \\
\hline $\begin{array}{l}\text { Environmental } \\
\text { management } \\
\text { systems }\end{array}$ & $75.4 / 24.6$ & 0.682 & 0.181 & 0.049 & 0.251 \\
\hline $\begin{array}{l}\text { Environmental } \\
\text { auditing }\end{array}$ & 88.0/12.0 & 0.175 & -0.076 & 0.610 & 0.330 \\
\hline $\begin{array}{l}\text { Environmental } \\
\text { marking }\end{array}$ & $85.8 / 14.2$ & 0.216 & 0.133 & 0.411 & 0.414 \\
\hline $\begin{array}{l}\text { Evaluation of } \\
\text { environmental } \\
\text { performance }\end{array}$ & $82.0 / 18.0$ & 0.006 & 0.352 & 0.199 & 0.622 \\
\hline $\begin{array}{l}\text { Product life cycle } \\
\text { assessment (LCA) }\end{array}$ & $79.2 / 20.8$ & 0.188 & -0.068 & -0.048 & 0.795 \\
\hline $\begin{array}{l}\text { Environmental } \\
\text { accounting }\end{array}$ & $96.2 / 7.8$ & -0.078 & 0.083 & 0.646 & -0.23 \\
\hline $\begin{array}{l}\text { Environmental } \\
\text { communication }\end{array}$ & $88.5 / 11.5$ & 0.140 & 0.619 & 0.298 & -0.005 \\
\hline $\begin{array}{l}\text { Methodology of } \\
\text { climatic activi- } \\
\text { ties and climate } \\
\text { change }\end{array}$ & $90.2 / 9.8$ & -0.196 & 0.612 & 0.190 & 0.374 \\
\hline $\begin{array}{l}\text { Reporting } \\
\text { focussed on sus- } \\
\text { tainable develop- } \\
\text { ment }\end{array}$ & $84.2 / 15.8$ & 0.262 & 0.253 & 0.325 & 0.190 \\
\hline CSR Report & $79.8 / 20.2$ & 0.170 & 0.395 & 0.501 & -0.034 \\
\hline $\begin{array}{l}\text { Total } \% \text { of vari- } \\
\text { ance }\end{array}$ & $x$ & 24.103 & 10.463 & 8.071 & 7.404 \\
\hline $\begin{array}{l}\text { Name of the } \\
\text { factor }\end{array}$ & $\times$ & $\begin{array}{l}\text { Integra- } \\
\text { tion of } \\
\text { the sys- } \\
\text { tems of } \\
\text { quality } \\
\text { manage- } \\
\text { ment, } \\
\text { OSH and } \\
\text { environ- } \\
\text { ment }\end{array}$ & $\begin{array}{l}\text { Environmen- } \\
\text { tal profile of } \\
\text { the enterprise } \\
\text { for economic } \\
\text { and social } \\
\text { affairs }\end{array}$ & $\begin{array}{l}\text { Voluntary } \\
\text { reporting of } \\
\text { environmen- } \\
\text { tal activities }\end{array}$ & $\begin{array}{l}\text { Evaluation } \\
\text { of envi- } \\
\text { ronmental } \\
\text { impacts }\end{array}$ \\
\hline
\end{tabular}


There are four identifiable factors listed in Table 5 related to approaches of enforcing the conception of sustainable development in the addressed Czech enterprises: 1) Integration of the systems of quality management, OSH, and environment; 2) Environmental profile of the enterprise for economic and social affairs; 3) Voluntary reporting of environmental activities, and 4) Evaluation of environmental impacts. The integration of management systems means reducing duplicity, increasing effectiveness, and preventing excessive paperwork in the integration of separate systems of quality, environment, and OSH management. These are not independent systems but rather part of the attitude of the management of the organisation as a whole and function across the organisation.

To ensure competitiveness, in-house management must be improved based on the process approach, effective simplification of operations, efficient production processes, reduced rate of scrap, and reduced consumption of energy and raw materials to keep overhead costs low. It is more advantageous for the organisation to behave in compliance with the law than to pay high fines for violation. This means that essential activities in the organisation are described in advance, and the powers and responsibilities of employees are determined. It also ensures that the risk of nonconforming products, ecological accidents, and the number of occupational injuries is reduced. This is in concordance with Hitka et al. (2021) and Stacho et al. (2020).

Based on the results, we can state that the favourable environmental profile of the enterprise for economic and social affairs can be ranked according to the key factors of sustainable business because increasing competition can be fought only if the enterprise has a high-quality product or service. Regarding the environmental communication with all stakeholders, a plan should be drawn, and it should include the way of communication, record and documentation, including protection of confidential information of a commercial or legal nature. The voluntary reporting of environmental activities reflects a high rate of correlation in environmental marking, auditing, and accounting. The main purpose of environmental marking is to encourage the demand and supply of products with demonstrably lower environmental burden by providing information about their impact on the environment. This includes eco-labelling of products with a lower negative impact on the environment and environmental affirmation as a form of declaration about the environmental aspects of the product, component, or packaging. Finally, the environmental product declaration also provides quantitative information about the product's impact on the environment. The environmental audit informs about the extent to which the enterprise complies with legislation concerning the environment and with its own directives, as well as how much it is known to be a part of the environmental management system, which is mandatory for companies with ISO 14001 or EMAS certification. Environmental accounting reflects the environmental profile as well as the economic and social performance of companies, thus providing information about the costs and benefits related to environmental issues. The evaluation of environmental impacts includes the evaluation of environmental performance and objective time- and cost-intensive product life cycle assessment, which consists of the collection of data, evaluation of inputs and outputs, and possible impacts on the environment during the products' life cycle. The importance of the evaluation of the environmental impacts is highlighted by Hayat et al. (2020) and Mapar et al. (2020), in accordance with the results of this study. Most representatives from the addressed agricultural enterprises agree that principles and instruments 
of sustainability implemented in agricultural activities are of key importance and linked with European traditions as they concern the safety of food products, negative externalities of food production, genetically modified organisms, use of pesticides and other chemical substances, welfare of animals, water and waste management, and many other issues. Czech farmers run their activities in both protected landscape areas, national parks, and production regions. All the respondents agree that it is necessary to continually accommodate the new findings of science and research, and at the same time, increase the efficiency of management because food security is an urgent need in connection with the growing population. They also claim that high productivity and sustainability are not in contradiction and that there is an increased emphasis on technology, innovations, and digitalisation in agriculture. The extent to which natural resources are positively or negatively affected (measurability of effects and influences is required) must be monitored, and preventive measures have to be adopted.

Based on the research results and interviews with the representatives of agricultural enterprises, it is expected that the social demand for ecosystem services as well as the emphasis on the responsible use of land and other key natural resources will increase. The growing influence of bioeconomy is likely to increase the demand for non-food biomass use, the need for response to climate change, and the urgency to efficiently apply the principles of the circular economy. The representatives of agricultural enterprises agree that research must respond to trends proactively, promote digitalisation in agriculture effectively, and utilise data in applying robotization and elements of precise agriculture, including biotechnologies. The results of this study expand the current research results (e.g. Tassinari et al., 2021; Hayat et al., 2020; Lovrić et al., 2017; Marchese et al., 2018). According to Mahdi et al. (2019) and Zhai et al. (2018), competitiveness can be achieved through sustainable performance. Haseeb et al. (2019) demonstrate that competitive advantage increases sustainable business performance. Hummels \& Argyrou (2021) point out that sustainable business can significantly contribute to enhancing the sustainability of the environment while establishing profitable businesses. Nevertheless, Salmivaara \& Kibler (2020) add that contemporary generations promote business activities that are presumed to contribute to sustainable development, but ignore the fact that business potentially brings negative externalities. Kuckertz \& Wagner (2010) further add to the theme of sustainable business that the objective of such enterprises is to handle the triple profit that Belz \& Binder (2017) specify as economic, social, and ecological, in their definition of sustainable business, as confirmed by this study.

According to these results, it can be summarised that the concept of sustainable development is neither novel in theory nor in practice. The authors agree that society has a limited amount of resources available nowadays, which has to be used with forethought. This is also confirmed by research studies published by Broman \& Robèrt (2017), Kajikawa et al. (2014), Orecchini et al. (2012), and Steffen et al. (2015), which are in line with the conclusions of this study. For example, there are state-imposed limits to development in various areas in terms of the quantitative growth of some indicators. However, there is no agreement on the quantity of such resources that are available to mankind and how long they would last.

Therefore, the application of some voluntary instruments, such as CSR, in agricultural enterprises has been addressed by several authors, including Bavorová et al. (2020), Mazur- 
Wierzbicka (2015), and Syamni (2018). In the Czech Republic, Haltofová \& Adámek (2014) have studied this. The research presented in this study links with their studies and complements them with sustainability factors monitored by Czech organisations. It should be mentioned that the current COVID-19 crisis is very problematic (Ou et al., 2021) for the agricultural sector as farmers supply food products to restaurants and catering facilities that are now closed. Jámbor et al. (2020) summarise the impact of the pandemic on agriculture as follows: limited supply of food products, panic shopping and hoarding, labour shortage, food security and safety issues, protectionist movements, problems with supplies, increased electronic shopping of agricultural products, etc.

Based on the above-stated facts, we can conclude that the instruments and approaches applied to improve performance and competitiveness are those presented in the reference section and demonstrated in the research results; however, they are efficient and functional only if the organisation applies the process management approach. Competitiveness is a multidimensional indicator of the capability to generate sustainable competitive advantages at both the national and corporate levels. The results show that the enterprises' commitment to sustainable development represents the potential to achieve a competitive advantage and increase the competitiveness of the enterprises in the market as a whole in every sector of the economy.

\section{CONCLUSION}

The results of the research show that processes and projects are evaluated in terms of their economic, environmental, and social aspects and impacts in majority of the addressed organisations, with more than 250 employees having the greatest share. However, one should be careful in interpreting this statement because a difference apparently exists between merely perceiving the importance of social responsibility from the perspective of the three pillars and the implementation of the respective policies. Four key factors are identified to play a role in ensuring sustainable business and competitiveness: integration of quality, environment, and OSH management systems; environmental profile of the organisation for economic and social affairs; voluntary reporting of environmental activities; and evaluation of environmental impacts. Enterprises should inevitably gain a competitive advantage in the form of a customer-oriented strategic management system consisting of continual improvement aimed at the best possible results, including return on investment.

Environmental devastation or threats to the health of personnel cannot be considered side products of processes affecting production quality from a system approach perspective. Activities related to ecology and the working environment are integral parts of all processes, from product formation to disposal. It is evident that inactivity toward climate change would result in cardinal socio-economic impacts and economic losses.

A theoretical contribution of this study is the summarisation of the different opinions of authors about sustainable business. A practical contribution is the presentation of results of the application of voluntary instruments of sustainable business and the evaluation of the current situation in the studied enterprises. A certain limiting factor of the present research is that the results are obtained from the questionnaire survey and interview responses provided by 
the representatives of organisations, while the effect of the voluntary instrument or product provided by the organisation is not evaluated. Therefore, the observations should be interpreted in the context of the presented research sample and generalised for the given sample only, as the respondents might tend to create a better image of their organisations and want to be more rational in their responses. A follow-up investigation will focus on the evaluation of the impact of individual voluntary instruments on the final products of organisations.

\section{References}

1. Ahi, P., \& Searcy, C. (2013). A comparative literature analysis of definitions for green and sustainable supply chain management. Journal of Cleaner Production, 52, 329-341. http://dx.doi. org/10.1016/j.jclepro.2013.02.018

2. Ahmed, M. (2020). Introduction to Modern Climate Change. Andrew E. Dessler: Cambridge University Press, 2011, 252 pp, ISBN-10: 0521173159. The Science of the Total Environment, 734, 139397. http://dx.doi.org/10.1016/j.scitotenv.2020.139397

3. Akhmadovich, K. Z. (2019). Synergy Effect Textile Clusters of Uzbekistan. Asian Journal of Technology \& Management Research, 9 (1)

4. Anderson, V. (2013). Research Method in Human Resource Management. London: Chartered Institute of Personnel Development.

5. Balasubramanian, S., \& Shukla, V. (2020). Foreign versus local firms: implications for environmental sustainability. Benchmarking: An International Journal, 27 (5), 1739-1768. http:// dx.doi.org/10.1108/BIJ-12-2019-0526

6. Bavorová, M., Bednarikova, Z., Ponkina, E. V., \& Visser, O. (2020). Agribusiness social responsibility in emerging economies: Effects of legal structure, economic performance and managers' motivations. Journal of Cleaner Production, 289, 125157. http://dx.doi.org/10.1016/j. jclepro.2020.125157

7. Belz, F. M., \& Binder, J. K. (2017). Sustainable entrepreneurship: A convergent process model. Business Strategy and the Environment, 26 (1), 1-17. http://dx.doi.org/10.1002/bse.1887

8. Bernal-Conesa, J. A., de Nieves Nieto, C., \& Briones-Peñalver, A. J. (2017). CSR strategy in technology companies: Its influence on performance, competitiveness and sustainability. Corporate Social Responsibility and Environmental Management, 24 (2), 96-107. http://dx.doi. org $/ 10.1002 /$ csr.1393

9. Bhardwaj, P., Chatterjee, P., Demir, K. D., \& Turut, O. (2018). When and how is corporate social responsibility profitable? Journal of Business Research, 84, 206-219. http://dx.doi. org/10.1016/j.jbusres.2017.11.026

10. Broman, G. I., \& Robèrt, K. H. (2017). A framework for strategic sustainable development. Journal of Cleaner Production, 140, 17-31. http://dx.doi.org/10.1016/j.jclepro.2015.10.121

11. Camacho, J., \& Fernandez, J. L. (2018). Competitiveness and CSR in SME: Results from a Study in the Madrid Region. Management Dynamics in the Knowledge Economy, 6 (1), 105-116. http://dx.doi.org/10.25019/mdke/6.1.06 
12. Cancino, C. A., La Paz, A. I., Ramaprasad, A., \& Syn, T. (2018). Technological innovation for sustainable growth: An ontological perspective. Journal of Cleaner Production, 179, 31-41. http:// dx.doi.org/10.1016/j.jclepro.2018.01.059

13. Ciccullo, F., Pero, M., Caridi, M., Gosling, J., \& Purvis, L. (2018). Integrating the environmental and social sustainability pillars into the lean and agile supply chain management paradigms: A literature review and future research directions. Journal of Cleaner Production, 172, 2336-2350. http://dx.doi.org/10.1016/j.jclepro.2017.11.176

14. Cuaresma, J. C., Fengler, W., Kharas, H., Bekhtiar, K., Brottrager, M., \& Hofer, M. (2018). Will the Sustainable Development Goals be fulfilled? Assessing present and future global poverty. Palgrave Communications, 4 (1), 1-8. http://dx.doi.org/10.1057/s41599-018-0083-y

15. Diffenbaugh, N. S., \& Burke, M. (2019). Global warming has increased global economic inequality. Proceedings of the National Academy of Sciences, 116 (20), 9808-9813. http://dx.doi. org/10.1073/pnas.1816020116

16. Drobyazko, S., Barwińska-Małajowicz, A., Ślusarczyk, B., Zavidna, L., \& DanylovychKropyvnytska, M. (2019). Innovative entrepreneurship models in the management system of enterprise competitiveness. Journal of Entrepreneurship Education, 22 (4), 1-6.

17. Evans, S., Vladimirova, D., Holgado, M., Van Fossen, K., Yang, M., Silva, E. A., \& Barlow, C. Y. (2017). Business model innovation for sustainability: Towards a unified perspective for creation of sustainable business models. Business Strategy and the Environment, 26 (5), 597-608. http://dx.doi.org/10.1002/bse.1939

18. Fischer, D., Haucke, F., \& Sundermann, A. (2017). What does the media mean by 'sustainability'or 'sustainable development'? An empirical analysis of sustainability terminology in German newspapers over two decades. Sustainable Development, 25 (6), 610-624. http://dx.doi.org/10.1002/sd.1681

19. Gallardo-Vázquez, D., \& Sanchez-Hernandez, M. I. (2014). Measuring Corporate Social Responsibility for competitive success at a regional level. Journal of Cleaner Production, 72, 14-22. http://dx.doi.org/10.1016/j.jclepro.2014.02.051

20. Geissdoerfer, M., Vladimirova, D., \& Evans, S. (2018). Sustainable business model innovation: A review. Journal of Cleaner Production, 198, 401-416. http://dx.doi.org/10.1016/j. jclepro.2018.06.240

21. Giang, N., Binh, T., Thuy, L., Ha, D., \& Loan, C. (2020). Environmental accounting for sustainable development: An empirical study in Vietnam. Management Science Letters, 10 (7), 1613-1622. http://dx.doi.org/10.5267/j.msl.2019.12.005

22. Gonzalez, E. D., Sarkis, J., Huisingh, D., Huatuco, L. H., Maculan, N., Montoya-Torres, J. R., \& de Almeida, C. M. (2015). Making real progress toward more sustainable societies using decision support models and tools: introduction to the special volume. Journal of Cleaner Production, 105, 1-13. http://dx.doi.org/10.1016/j.jclepro.2015.05.047

23. Hadj, T. B. (2020). Effects of corporate social responsibility towards stakeholders and environmental management on responsible innovation and competitiveness. Journal of Cleaner Production, 250, 119490. http://dx.doi.org/10.1016/j.jclepro.2019.119490 
24. Hák, T., Janoušková, S., \& Moldan, B. (2016). Sustainable Development Goals: A need for relevant indicators. Ecological Indicators, 60, 565-573. http://dx.doi.org/10.1016/j. ecolind.2015.08.003

25. Haltofová, P., \& Adámek, P. (2014). Corporate social responsibility in companies of the primary sector in the Czech Republic, a preliminary study. Procedia Economics and Finance, 12, 206-212. http://dx.doi.org/10.1016/s2212-5671(14)00337-2

26. Haseeb, M., Hussain, H. I., Kot, S., Androniceanu, A., \& Jermsittiparsert, K. (2019). Role of social and technological challenges in achieving a sustainable competitive advantage and sustainable business performance. Sustainability, 11 (14), 3811. http://dx.doi.org/10.3390/ su11143811

27. Hayat, N., Hussain, A., \& Lohano, H. D. (2020). Eco-labeling and sustainability: A case of textile industry in Pakistan. Journal of Cleaner Production, 252, 119807. http://dx.doi. org/10.1016/j.jclepro.2019.119807

28. Hitka, M., Schmidtova, J., Lorincova, S., Starchon, P., Weberova D, Kampf, R. (2021). Sustainability of Human Resource Management Processes through Employee Motivation and Job Satisfaction. Acta Polytechnica Hungarica, 18 (2), 7-26. http://dx.doi.org/10.12700/ APH.18.2.2021.2.1

29. Hummels, H., \& Argyrou, A. (2021). Planetary demands: Redefining sustainable development and sustainable entrepreneurship. Journal of Cleaner Production, 278, 123804. http://dx.doi. org/10.1016/j.jclepro.2020.123804

30. Hung, S. W., Li, C. M., \& Lee, J. M. (2019). Firm growth, business risk, and corporate social responsibility in Taiwan's food industry. Agricultural Economics, 65 (8), 366-374. http://dx.doi. org/10.17221/339/2018-AGRICECON

31. Jámbor, A., Czine, P., \& Balogh, P. (2020). The Impact of the Coronavirus on Agriculture: First Evidence Based on Global Newspapers. Sustainability, 12 (11), 4535. http://dx.doi. org $/ 10.3390 /$ su12114535

32. Jilcha, K., \& Kitaw, D. (2017). Industrial occupational safety and health innovation for sustainable development. Engineering Science and Technology, an International Journal, 20 (1), 372-380. http://dx.doi.org/10.1016/j.jestch.2016.10.011

33. Jorge, M. L., Madueño, J. H., Martinez-Martinez, D., \& Sancho, M. P. L. (2015). Competitiveness and environmental performance in Spanish small and medium enterprises: is there a direct link? Journal of Cleaner Production, 101, 26-37. http://dx.doi.org/10.1016/j. jclepro.2015.04.016

34. Joyce, A., \& Paquin, R. L. (2016). The triple-layered business model canvas: A tool to design more sustainable business models. Journal of Cleaner Production, 135, 1474-1486. http://dx.doi. org/10.1016/j.jclepro.2016.06.067

35. Kaiser H.F. (1958). The varimax criterion for analytic rotation in factor analysis. Psychometrika, 23, 187-200. http://dx.doi.org/10.1007/BF02289233

36. Kajikawa, Y., Tacoa, F., \& Yamaguchi, K. (2014). Sustainability science: the changing landscape of sustainability research. Sustainability Science, 9 (4), 431-438. http://dx.doi. org/10.1007/s11625-014-0244-x 
37. Kolk, A., \& Van Tulder, R. (2010). International business, corporate social responsibility and sustainable development. International Business Review, 19 (2), 119-125. http://dx.doi. $\operatorname{org} / 10.1016 /$ j.ibusrev.2009.12.003

38. Kopnina, H. (2017). Sustainability: new strategic thinking for business. Environment, Development and Sustainability, 19 (1), 27-43. http://dx.doi.org/10.1007/s10668-015-9723-1

39. Kuckertz, A., \& Wagner, M. (2010). The influence of sustainability orientation on entrepreneurial intentions-Investigating the role of business experience. Journal of business venturing, 25 (5), 524-539. http://dx.doi.org/10.1016/j.jbusvent.2009.09.001

40. Lopez, B. (2020). Connecting business and sustainable development goals in Spain. Marketing Intelligence \& Planning, 38 (5), 573-585. http://dx.doi.org/10.1108/MIP-08-2018-0367

41. Lovrić, M., Lovrić, N., \& Mavsar, R. (2017). Synthesis on forest bioeconomy research and innovation in Europe. European Forest Institute, 1-64.

42. Lozano, R. (2015). A holistic perspective on corporate sustainability drivers. Corporate social responsibility and environmental management, 22 (1), 32-44. http://dx.doi.org/10.1002/csr.1325

43. Lüdeke-Freund, F., \& Dembek, K. (2017). Sustainable business model research and practice: Emerging field or passing fancy? Journal of Cleaner Production, 168, 1668-1678. http://dx.doi. org/10.1016/j.jclepro.2017.08.093

44. Mahdi, O. R., Nassar, I. A., \& Almsafir, M. K. (2019). Knowledge management processes and sustainable competitive advantage: An empirical examination in private universities. Journal of Business Research, 94, 320-334. http://dx.doi.org/10.1016/j.jbusres.2018.02.013

45. Mapar, M., Jafari, M. J., Mansouri, N., Arjmandi, R., Azizinejad, R., \& Ramos, T. B. (2017). Sustainability indicators for municipalities of megacities: Integrating health, safety and environmental performance. Ecological Indicators, 83, 271-291. http://dx.doi.org/10.1016/j. ecolind.2017.08.012

46. Marchese, D., Reynolds, E., Bates, M. E., Morgan, H., Clark, S. S., \& Linkov, I. (2018). Resilience and sustainability: Similarities and differences in environmental management applications. Science of the Total Environment, 613, 1275-1283. http://dx.doi.org/10.1016/j. scitotenv.2017.09.086

47. Marin, L., Martín, P. J., \& Rubio, A. (2017). Doing good and different! The mediation effect of innovation and investment on the influence of CSR on competitiveness. Corporate Social Responsibility and Environmental Management, 24 (2), 159-171. http://dx.doi.org/10.1002/csr.1412

48. Mazur-Wierzbicka, E. (2015). The application of corporate social responsibility in European agriculture. Miscellanea Geographica, 19 (1), 19-23. http://dx.doi.org/10.1515/mgrsd-2015-0001

49. McGreavy, B., Druschke, C. G., Sprain, L., Thompson, J. L., \& Lindenfeld, L. A. (2016). Environmental communication pedagogy for sustainability: Developing core capacities to engage with complex problems. Applied Environmental Education \& Communication, 15 (3), 261-274. http://dx.doi.org/10.1080/1533015X.2016.1181018

50. Missimer, M., Robèrt, K. H., \& Broman, G. (2017). A strategic approach to social sustainability-Part 1: exploring the social system. Journal of Cleaner Production, 140, 32-41. http://dx.doi.org/10.1016/j.jclepro.2016.03.170 
51. Mustapha, M. A., Manan, Z. A., \& Alwi, S. R. W. (2017). Sustainable Green Management System (SGMS)-An integrated approach towards organisational sustainability. Journal of Cleaner Production, 146, 158-172. http://dx.doi.org/10.1016/j.jclepro.2016.06.033

52. Nguyen, M. H., Phan, A. C., \& Matsui, Y. (2018). Contribution of quality management practices to sustainability performance of Vietnamese firms. Sustainability, 10 (2), 375. http:// dx.doi.org/10.3390/su10020375

53. Nosratabadi, S., Mosavi, A., Shamshirband, S., Kazimieras Zavadskas, E., Rakotonirainy, A., \& Chau, K. W. (2019). Sustainable business models: A review. Sustainability, 11 (6), 1663. http:// dx.doi.org/10.3390/su11061663

54. Nyuur, R. B., Ofori, D. F., \& Amponsah, M. M. (2019). Corporate social responsibility and competitive advantage: A developing country perspective. Thunderbird International Business Review, 61 (4), 551-564. http://dx.doi.org/10.1002/tie.22065

55. O'Flaherty, J., \& Liddy, M. (2018). The impact of development education and education for sustainable development interventions: a synthesis of the research. Environmental Education Research, 24 (7), 1031-1049. http://dx.doi.org/10.1080/13504622.2017.1392484

56. Olsson, P., Moore, M. L., Westley, F. R., \& McCarthy, D. D. (2017). The concept of the Anthropocene as a game-changer: a new context for social innovation and transformations to sustainability. Ecology and Society, 22 (2). http://dx.doi.org/10.5751/ES-09310-220231

57. Orecchini, F., Valitutti, V., \& Vitali, G. (2012). Industry and academia for a transition towards sustainability: advancing sustainability science through university-business collaborations. Sustainability science, 7 (1), 57-73. http://dx.doi.org/10.1007/s11625-011-0151-3

58. Ou, J., Wong, I. A., \& Huang, G. I. (2021). The coevolutionary process of restaurant CSR in the time of mega disruption. International Journal of Hospitality Management, 92, 102684. http:// dx.doi.org/10.1016/j.ijhm.2020.102684

59. Petřriček, M., Chalupa, Š., \& Levičková, V. (2021). Comparison of expected marginal revenue models in the hospitality industry. Journal of Revenue and Pricing Management, 1-7. http://dx.doi. org/10.1057/s41272-021-00328-9

60. Rauter, R., Jonker, J., \& Baumgartner, R. J. (2017). Going one's own way: drivers in developing business models for sustainability. Journal of Cleaner Production, 140, 144-154. http://dx.doi. org/10.1016/j.jclepro.2015.04.104

61. Ren, M., Ren, L., \& Jain, H. (2018). Manufacturing service composition model based on synergy effect: a social network analysis approach. Applied Soft Computing, 70, 288-300. http:// dx.doi.org/10.1016/j.asoc.2018.05.039

62. Salmivaara, V., \& Kibler, E. (2020). "Rhetoric Mix" of Argumentations: How Policy Rhetoric Conveys Meaning of Entrepreneurship for Sustainable Development. Entrepreneurship Theory and Practice, 44 (4), 700-732. https://doi.org/10.1177/1042258719845345

63. Spangenberg, J. H. (2011). Sustainability science: a renview, an analysis and some empirical lessons. Environmental Conservation, 38 (3), 275-287. http://dx.doi.org/10.1017/ S0376892911000270. 
64. Stacho, Z., Stachova K., \& Caganova, D. (2020). Participation of all Employee Categories in Innovation Processes in Slovak Organisations. Mobile Networks and Applications, 25 (3), 853-859. http://dx.doi.org/10.1007/s11036-020-01518-2

65. Steffen, W., Richardson, K., Rockström, J., Cornell, S. E., Fetzer, I., Bennett, E. M., Biggs, R., Carpenter, S. R., Vries, W. D., De Wit, C. A., Folke, C., Gerten, D., Heinke, J., Mace, G. M., Persson, L. M., Ramanathan, V., Reyers, B. \& Sörlin, S. (2015). Planetary boundaries: Guiding human development on a changing planet. Science, 347 (6223). http://dx.doi.org/10.1126/ science. 1259855

66. Stubbs, W. (2017). Characterising B Corps as a sustainable business model: An exploratory study of B Corps in Australia. Journal of Cleaner Production, 144, 299-312. http://dx.doi. org/10.1016/j.jclepro.2016.12.093

67. Syamni, G. (2018). CSR and Profitability in IDX Agricultural Subsectors. In Proceedings of MICoMS 2017. Emerald Publishing Limited. http://dx.doi.org/10.1108/978-1-78756-793-100034

68. Tarquinio, L., Raucci, D., \& Benedetti, R. (2018). An investigation of global reporting initiative performance indicators in corporate sustainability reports: Greek, Italian and Spanish evidence. Sustainability, 10 (4), 897. http://dx.doi.org/10.3390/su10040897

69. Tassinari G., Drabik D., Boccaletti S., \& Soregaroli C. (2021). Case studies research in the bioeconomy: A systematic literature review. Agricultural Economics = Zemedelská ekonomika, 67 (7), 286-303. https://doi.org/10.17221/21/2021-AGRICECON

70. Van Marrewijk, M. (2003). Concepts and definitions of CSR and corporate sustainability: Between agency and communion. Journal of Business Ethics, 44 (2), 95-105. http://dx.doi. org/10.1023/A:1023331212247

71. Wiek, A., Farioli, F., Fukushi, K., \& Yarime, M. (2012). Sustainability science: bridging the gap between science and society. Sustainability Science, 7 (1), 1-4. http://dx.doi.org/10.1007/s11625011-0154-0

72. Young, W., \& Tilley, F. (2006). Can sustainable entrepreneurs become the true wealth generators of the future. Greener Management International, 55, 19-92. http://dx.doi.org/10.9774/ gleaf.3062.2006.au.00008

73. Yu, H. C., Kuo, L., \& Kao, M. F. (2017). The relationship between CSR disclosure and competitive advantage. Sustainability Accounting, Management and Policy Journal, 8 (5), 547-570. http://dx.doi.org/10.1108/SAMPJ-11-2016-0086

74. Zemigala, M. (2019). Tendencies in research on sustainable development in management sciences. Journal of Cleaner Production, 218, 796-809. http://dx.doi.org/10.1016/j. jclepro.2019.02.009

75. Zhai, Y. M., Sun, W. Q., Tsai, S. B., Wang, Z., Zhao, Y., \& Chen, Q. (2018). An empirical study on entrepreneurial orientation, absorptive capacity, and SMEs' innovation performance: A sustainable perspective. Sustainability, 10 (2), 314.

76. Zu, L. (2019). Purpose-driven leadership for sustainable business: From the Perspective of Taoism. International Journal of Corporate Social Responsibility, 4 (1), 1-31. http://dx.doi. org/10.1186/s40991-019-0041-z 


\section{Contact information}

Ing. Pavla Vrabcova, Ph.D.

Czech University of Life Sciences Prague

Faculty of Forestry and Wood Sciences

Department of Forestry and Wood Economics

Crech Republic

E-mail:vrabcovapavla@gmail.com

ORCID:0000-0002-4384-1622

Ing. Hana Urbancova, Ph.D.

University of Economics and Management

Department of Human Resources

Czech Republic

E-mail:bana.urbancova@vsem.cr.

ORCID: 0000-0001-6603-8691 